\title{
Pharmacologically relevant drug interactions of sulfonylurea antidiabetics with common herbs
}

\author{
Naina Mohamed Pakkir Maideen ${ }^{1 *}$, Rajkapoor Balasubramaniam ${ }^{2}$ \\ ${ }^{1}$ Dubai Health Authority, Dubai, United Arab Emirates \\ ${ }^{2}$ Department of Pharmacology, School of Pharmacy, Mekelle University, Ethiopia
}

\section{A R T I C L E I N F O}

Article Type:

Review Article

\section{Article History:}

Received: 7 February 2018

Accepted: 29 June 2018

\section{Keywords:}

Sulfonylureas

Antidiabetic herbs

Drug Interactions

Pharmacokinetic interactions

Pharmacodynamic Interactions

\begin{abstract}
A B S T RA C T
Introduction: Sulfonylurea antidiabetics are insulin secretogogues useful in the treatment of type 2 diabetic patients. The probability of adverse drug interactions is high in patients taking sulfonylureas and other drugs including herbal medicines. The present review is aimed to present the herbal drugs having interacting potentials with sulfonylurea antidiabetics.

Methods: The databases such as PubMed, Google Scholar, Science Direct, Directory of open access journals (DOAJ) and reference lists were searched using the keywords drug interactions, Sulfonylureas, pharmacodynamic interactions, antidiabetic herbs, pharmacokinetic interactions and CYP2C9.

Results: Sulfonylureas are primarily metabolized by CYP2C9 enzyme and the herbs like St. John's wort and Ginkgo biloba induce CYP2C9-mediated metabolism of sulfonylureas while fruit juices like Pomegranate juice and Pineapple juice inhibit their metabolism. In addition, the antidiabetic herbal supplements such as Bitter melon, Fenugreek, Cinnamon, Gymnema, Ginseng, Ginger, Garlic, Aloe vera, Sesame, Andrographis paniculata and Neem potentiate the hypoglycemic activity of sulfonylureas, pharmacodynamically.

Conclusion: Some herbal supplements are capable of interacting pharmacokinetically and pharmacodynamically with sulfonylurea antidiabetics
\end{abstract}

Implication for health policy/practice/research/medical education:

Due to the possible interaction of herbal supplements with sulfonylurea antidiabetics, prescribers and pharmacists are required to be aware of these drug interactions to avoid the possible problems for patients.

Please cite this paper as: Pakkir Maideen NM, Balasubramaniam R. Pharmacologically relevant drug interactions of sulfonylurea antidiabetics with common herbs. J Herbmed Pharmacol. 2018;7(3):200-210. doi: 10.15171/jhp.2018.32.

\section{Introduction}

Diabetes mellitus (DM) is a chronic metabolic condition in which hyperglycemia is noted for a longer duration (1). It is a global health burden and the incidence of diabetes among global population is increasing every year. It has been estimated that 171 million of world population were affected by diabetes in the year of 2000 (2), 285 million in 2010 (3), 366 million in 2011 (4), 382 million in 2013 (5), 415 million in 2015 (6) and 451 million in 2017 (7). The prevalence of diabetes around the globe has been projected as 552 million by 2030 (8), 592 million by 2035 (9), 642 million by 2040 (10) and 693 million by 2045 (11). DM is sorted mainly as type 1 DM which is insulindependent (IDDM) and type $2 \mathrm{DM}$, the non-insulin dependent (NIDDM). DM could be managed by both non-pharmacological and pharmacological therapies. Non-pharmacological management of diabetes includes lifestyle modifications such as dietary interventions, increased physical activity and smoking cessation. (12). Type 1 diabetes is managed pharmacologically by administering insulin injections mainly and the pharmacological management of type 2 diabetes includes the use of antidiabetic medications such as metformin, sulfonylureas, meglitinides (repaglinide and nateglinide), thiazolidinediones (rosiglitazone and pioglitazone), alpha glucosidase inhibitors (acarbose and miglitol), dipeptidyl peptidase 4 (DPP4) inhibitors (sitagliptin, saxagliptin, linagliptin, etc), SGLT2 inhibitors (dapagliflozin,

*Corresponding author: Dr. Naina Mohamed Pakkir Maideen PhD, Pharmacologist, Dubai Health Authority, PB No: 4545, Dubai, UAE. Telephone: +97142164952, +971505769833 Fax: +97142244302 Email: nmmaideen@dha.gov.ae 
canagliflozin, etc.), GLP-1 agonists (exenatide, liraglutide, etc) and amylin analogue (pramlintide) (13).

Sulfonylurea antidiabetics reduce the blood sugar levels by inducing the release of insulin from beta cells of pancreas (14). They include first-generation drugs such as Tolbutamide, Chlorpropamide, etc and second-generation drugs like gliclazide, glipizide, glibenclamide, etc (15). Nowadays, the use of complementary and alternative medicine (CAM) is common amongst patients with diabetes and other common chronic problems. It has been estimated that $9.8 \%-76.0 \%$ of general population tend to use CAM, globally (16). The CAM use found high in people such as women, those with literacy, those with employment, those with poor physical health, and those with diabetes or its comorbidities (17). Furthermore, it has been reported that the prevalence of CAM use in patients with diabetes is approximately $48 \%$ (18). The most frequently used CAM treatments among patients with diabetes include herbal medicines, nutritional advice, spiritual healing, massage, and meditation (19).

Herbal supplement use is getting popular among general population. A study from the United States found that approximately $35 \%$ of 26157 participants used at least one herbal supplement (20). Up to $80 \%$ of population in developing countries use traditional herbal medicines as World Health Organization estimated it (21).

A study from Saudi Arabia comprising 228 patients with diabetes revealed that $24.6 \%$ of participants used herbal supplements (22) and an Iraqi study conducted among 884 diabetic patients found that $17.3 \%$ (153 respondents) of them used herbal supplements (23).

Drug interaction is defined as the interference of effects of one drug by the co-administered drugs, herbs, alcohol or tobacco smoke (24). The drug interaction leading to undesirable effects such as increased adverse effects or decreased beneficial effects, is termed adverse drug interaction'. The patients with diabetes are at heightened risk of adverse drug interactions, as they concomitantly use many medications to manage their comorbidities such as hypertension, dyslipidemia, heart diseases, depression, infections, etc, along with their antidiabetic medications (25). The probability of adverse drug interactions in diabetic patients is particularly high in patients who use sulfonylureas with herbal medicines. The present review is aimed to present the herbal drugs having interacting potentials with sulfonylurea antidiabetics.

\section{Methods}

The literature was searched in databases such as PubMed, Google Scholar, Science Direct, Directory of open access journals (DOAJ) and reference lists were searched using the keywords Drug interactions, Sulfonylureas, Pharmacodynamic interactions, Antidiabetic herbs, Pharmacokinetic interactions and CYP2C9.

\section{Results}

The herbal supplements taken by diabetic patients may interact with sulfonylureas either pharmacokinetically or pharmacodynamically. Sulfonylurea antidiabetics are metabolised primarily by cytochrome P450 2C9 (CYP2C9) enzyme (26) and by CYP3A4 enzyme to a lesser extent (27). Hence, the herbal drugs capable of modulating CYP enzymes may interact with sulfonylureas, pharmacokinetically (Table 1). As it was stated sulfonylureas are potent antidiabetic drugs and their concomitant use with certain herbs having antidiabetic activity may enhance the risk of hypoglycemia (Table 2).

\section{St John's Wort (Hypericum perforatum)}

St John's Wort is a herbal drug popularly used to treat depression. It can induce many CYP enzymes including CYP3A4 and CYP2C9 (28). The plasma concentrations of gliclazide decreased due to the concomitant use of St John's Wort, which could induce the CYP-mediated metabolism of gliclazide. It is recommended to monitor the signs of reduced hypoglycemic activity of sulfonylureas in patients with diabetes taking the combination of sulfonylureas and St John's Wort (29).

\section{Ginkgo biloba}

Ginkgo biloba may be useful to treat some neurological, psychological, and behavioral disorders.

The animal (30) and clinical (31) studies have identified that CYP2C9-mediated metabolism of tolbutamide

Table 1. Pharmacokinetic Herb - Sulfonylureas Interactions

\begin{tabular}{lll}
\hline Interacting Drugs & Mechanism of Interaction & Comments \\
\hline $\begin{array}{l}\text { St John's Wort (Hypericum } \\
\text { perforatum) }\end{array}$ & $\begin{array}{l}\text { St John's Wort may induce CYP-mediated } \\
\text { metabolism of sulfonylureas and } \\
\text { decrease their plasma concentrations. } \\
\text { Ginkgo biloba may decrease the plasma } \\
\text { concentrations of sulfonylureas (31). }\end{array}$ & $\begin{array}{l}\text { Monitor the signs of reduced hypoglycemic activity of } \\
\text { sulfonylureas in patients with diabetes taking the combination } \\
\text { of sulfonylureas and St John's Wort (29). }\end{array}$ \\
$\begin{array}{ll}\text { Pomegranate (Punica granatum) } \\
\text { Juice }\end{array}$ & $\begin{array}{l}\text { Pomegranate Juice may inhibit CYP2C9- } \\
\text { mediated metabolism of sulfonylureas. }\end{array}$ & $\begin{array}{l}\text { Pomegranate Juice potentiate the hypoglycemic effect of } \\
\text { tolbutamide (32). }\end{array}$ \\
Pineapple juice & $\begin{array}{l}\text { The pineapple juice may inhibit the } \\
\text { CYP2C9-mediated metabolism of }\end{array}$ & $\begin{array}{l}\text { The plasma concentrations of sulfonylureas might be elevated } \\
\text { by pineapple juice. }\end{array}$ \\
\hline
\end{tabular}


Table 2. Pharmacodynamic herb - sulfonylureas interactions

\begin{tabular}{|c|c|c|}
\hline Interacting Drugs & Mechanism of Interaction & Comments \\
\hline $\begin{array}{l}\text { Bitter melon } \\
\text { (Karela) (Momordica } \\
\text { charantia) }\end{array}$ & $\begin{array}{l}\text { Bitter melon may reduce blood sugar by exhibiting sulfonylurea like } \\
\text { activity }(35) \text {, improving glucose tolerance }(36,37) \text {, decreasing insulin } \\
\text { resistance }(38) \text {, increasing tissue glucose uptake }(39,40) \text { or by increasing } \\
\text { insulin sensitivity (41). }\end{array}$ & $\begin{array}{l}\text { Additive reductions in blood glucose may } \\
\text { result if sulfonylureas are used in patients } \\
\text { consuming bitter melon regularly (43). }\end{array}$ \\
\hline $\begin{array}{l}\text { Fenugreek } \\
\text { (Trigonella foenum- } \\
\text { graceum) }\end{array}$ & $\begin{array}{l}\text { Fenugreek may exert its hypoglycemic activity through improved insulin } \\
\text { resistance in adipocytes (47) and liver (48), enhanced glucose uptake } \\
\text { (49), increased activities of hepatic enzymes such as glucokinase and } \\
\text { hexokinase (50), elevation of serum insulin levels (51) and increased } \\
\text { insulin sensitivity (52). }\end{array}$ & $\begin{array}{l}\text { Fenugreek use in patients taking } \\
\text { sulfonylureas may further decrease the } \\
\text { blood glucose levels }(53,54) \text {. }\end{array}$ \\
\hline Cinnamon & $\begin{array}{l}\text { Antihyperglycemic effect of Cinnamon may occur through insulin mimetic } \\
\text { activity }(59,60) \text {, reduction of insulin resistance }(61,62) \text {, inhibition of } \\
\text { pancreatic } \alpha \text {-amylase and } \alpha \text {-glucosidase enzymes }(63) \text {, enhancement of } \\
\text { glucose uptake (64), stimulation of glycogen synthesis }(65) \text {, inhibition of } \\
\text { gluconeogenesis }(66) \text { and delayed gastric emptying (67). }\end{array}$ & $\begin{array}{l}\text { The dose of sulfonylureas may need to be } \\
\text { adjusted if the patient is taking cinnamon } \\
\text { concurrently (68). }\end{array}$ \\
\hline $\begin{array}{l}\text { Gymnema } \\
\text { (Gymnema sylvestre) }\end{array}$ & $\begin{array}{l}\text { Gymnema may reduce the glucose levels by delaying glucose absorption } \\
\text { (74), enhancing insulin secretion (75-77), increasing glucose uptake in } \\
\text { the liver, kidney and muscle }(78) \text { and inducing repair or regeneration of } \\
\text { pancreatic beta cells }(79,80) \text {. }\end{array}$ & $\begin{array}{l}\text { Concomitant use of sulfonylureas and } \\
\text { Gymnema may result in potentiation of } \\
\text { hypoglycemic effects }(81,82) \text {. }\end{array}$ \\
\hline Ginseng & $\begin{array}{l}\text { Ginseng may produce its antihyperglycemic activity by stimulating insulin } \\
\text { production and preventing } \beta \text { cell loss }(87-89) \text {, stimulating insulin release } \\
(90-93) \text {, improving insulin sensitivity }(94-96) \text {, decreasing insulin resistance } \\
(97,98) \text {, increasing glucose uptake }(99-101) \text {, suppressing hepatic glucose } \\
\text { production }(102,103) \text {, improving the regulation of plasma glucose } \\
\text { and plasma insulin (104) and improving the expression of Peroxisome } \\
\text { proliferator-activated receptors (PPAR })(105,106) \text {. }\end{array}$ & $\begin{array}{l}\text { Ginseng may potentiate the hypoglycemic } \\
\text { activity of sulfonylureas (107). }\end{array}$ \\
\hline $\begin{array}{l}\text { Ginger (Zingiber } \\
\text { officinale) }\end{array}$ & $\begin{array}{l}\text { Ginger may exhibit its antihyperglycemic activity through improvement } \\
\text { of insulin resistance }(111,112) \text {, enhancement of glucose uptake (113, } \\
\text { 114), increased insulin synthesis (115), decreased gluconeogenesis } \\
\text { and glycogenolysis and increased glycogenesis (116) and inhibition of } \\
\alpha \text {-glucosidase and } \alpha \text {-amylase enzymes (117). }\end{array}$ & $\begin{array}{l}\text { The blood glucose levels should be } \\
\text { monitored in patients taking sulfonylureas } \\
\text { and ginger together, to avoid the } \\
\text { occurrence of hypoglycemia (118). }\end{array}$ \\
\hline $\begin{array}{l}\text { Garlic (Allium } \\
\text { Sativum) }\end{array}$ & $\begin{array}{l}\text { Garlic may decrease the blood glucose levels through direct or indirect } \\
\text { stimulation of insulin secretion }(123,124) \text {, enhanced glucose utilization } \\
\text { (125) and slowing down glucose absorption (126). }\end{array}$ & $\begin{array}{l}\text { Caution should be applied in patients } \\
\text { taking sulfonylureas and garlic together } \\
(127,128) \text {. }\end{array}$ \\
\hline $\begin{array}{l}\text { Aloe vera (Aloe } \\
\text { barbadensis Miller) }\end{array}$ & $\begin{array}{l}\text { Aloe vera may exert it's hypoglycemic activity by improving insulin } \\
\text { resistance (135-137), stimulating the release of insulin (138), inhibiting } \\
\text { pancreatic } \alpha \text {-amylase activity (139), increasing glucose utilization and } \\
\text { suppressing glucose production (140). }\end{array}$ & $\begin{array}{l}\text { Aloe vera can potentiate the hypoglycemic } \\
\text { effect of sulfonylureas (141). }\end{array}$ \\
\hline $\begin{array}{l}\text { Sesame oil } \\
\text { [Sesamum indicum] }\end{array}$ & $\begin{array}{l}\text { Diabetes patients may prefer sesame oil as it reduces the detrimental } \\
\text { effects of diabetes by improving glucose control, blood pressure, lipid } \\
\text { levels and cardiac and renal health (149-152). }\end{array}$ & $\begin{array}{l}\text { Sesame oil may improve hyperglycemia of } \\
\text { patients taking sulfonylureas (153). }\end{array}$ \\
\hline $\begin{array}{l}\text { Andrographis } \\
\text { paniculata }\end{array}$ & $\begin{array}{l}\text { Androdrographolide of Andrographis paniculata reduced the plasma } \\
\text { glucose in streptozotocin-induced diabetic rats by increasing glucose } \\
\text { utilization (154). }\end{array}$ & $\begin{array}{l}\text { Use Andrographis paniculata } \\
\text { (Androdrographolide) with caution in } \\
\text { patients taking sulfonylureas to avoid the } \\
\text { risk of hypoglycemia (155). }\end{array}$ \\
\hline $\begin{array}{l}\text { Neem (Azadirachta } \\
\text { indica) }\end{array}$ & $\begin{array}{l}\text { A. indica found to decrease the blood glucose level by improving } \\
\text { carbohydrate metabolism through the stimulation of the } \beta \text {-cells in } \\
\text { streptozotocin-induced diabetic mice (157). }\end{array}$ & $\begin{array}{l}\text { Concomitant use of aqueous extract of } \\
\text { A. indica with gliclazide produced good } \\
\text { control of blood glucose (158). }\end{array}$ \\
\hline
\end{tabular}

is induced significantly by G. biloba extract, resulting in decreased plasma concentrations and reduced hypoglycemic effect of tolbutamide.

Pomegranate (Punica granatum) juice Pomegranate juice may inhibit CYP2C9 activity and increase the plasma concentration of tolbutamide resulting in potentiation of the hypoglycemic effect (32).

Pineapple juice

Pineapple juice contains bromelain as the principal component and it has been shown that CYP2C9 activity 
is inhibited strongly by Pineapple juice in vitro (33). The pineapple juice may inhibit the CYP2C9-mediated metabolism of sulfonylureas and elevate their plasma concentrations due to its very strong CYP2C9 inhibitory activity, in vitro.

In the following section the possible interaction of sulfonylureas with medicinal plants which have antidiabetic activities are presented.

\section{Bitter melon or bitter gourd (Momordica charantia)}

Bitter melon (Karela) is a tropical and subtropical vegetable and it is used traditionally to treat diabetes, abdominal pain, jaundice, cough, respiratory diseases, skin diseases, wounds, ulcer, gout and rheumatism, etc (34). It is commonly included in Asian diet. Bitter melon may reduce blood sugar by exhibiting sulfonylurea like activity (35), improving glucose tolerance $(36,37)$, decreasing insulin resistance (38), increasing tissue glucose uptake $(39,40)$ or by increasing insulin sensitivity $(41)$. The active principles, which may be responsible for the hypoglycemic activity of bitter melon, include polypeptide $\mathrm{P}$, momordin, charantin and vicine (42).

Additive reductions in blood glucose may result if sulfonylureas are used in patients consuming bitter melon regularly. Potentiation of hypoglycemic activity of glibenclamide was also noted in patients taking bitter melon extract (43). Blood sugar should be monitored and the dosage adjustment of sulfonylureas may be necessary to avoid hypoglycemic complications.

\section{Fenugreek (Trigonella foenum-graceum)}

Fenugreek is a popular condiment and is largely produced in Indian subcontinent. Traditional uses of fenugreek include antidiabetic, analgesic, anti-inflammatory, antiatherosclerotic, carminative, laxative, antispasmodic, anticancer, sexual stimulant, astringent, cardio tonic, antihypertensive, anti-triglyceridemic, lactation stimulant and oxytocic (44). Fenugreek contains constituents like carbohydrates, proteins, lipids, alkaloids, flavonoids, fibers, saponins, steroidal saponins, vitamins, minerals, etc (45). But, the hypoglycemic activity of fenugreek majorly determined by the active principles such as 4-hydroxyleucine, galactomannan rich fiber, and saponins (46). Fenugreek may exert its hypoglycemic activity through improved insulin resistance in adipocytes (47) and liver (48), enhanced glucose uptake (49), increased activities of hepatic enzymes such as glucokinase and hexokinase (50), elevation of serum insulin levels (51), and increased insulin sensitivity (52). Fenugreek use in patients taking sulfonylureas may further decrease the blood glucose levels $(53,54)$.

Fenugreek seed extract exhibited synergistic effect on hypoglycemic potential of glibenclamide. Caution is advised in patients taking an antidiabetic drug and a herb like Fenugreek concomitantly, to prevent hypoglycemic complications (55).

\section{Cinnamon}

Cinnamon is an inner bark of the trees of the genus Cinnamomum. Cinnamon is commonly used as a spice in many countries. There are many species of cinnamon available all around the world, which includes True cinnamon or Sri Lanka cinnamon or Ceylon cinnamon (Cinnamomum verum or Cinnamomum zeylanicum), Chinese cinnamon or cassia cinnamon (Cinnamomum cassia), Indonesian cinnamon (Cinnamomum burmannii), Vietnamese cinnamon or Saigon cinnamon (Cinnamomum loureiroi), etc (56). Many studies have confirmed that Cinnamon possesses antidiabetic, cholesterol-lowering, antioxidant, antitumor, anti-inflammatory, antimicrobial, cardio-vascular and immunomodulatory effects (57). Active chemical constituents of cinnamon include cinnamaldehyde, coumarins, essential oils, procyanidins, etc (58). Antihyperglycemic effect of Cinnamon may occur through insulin mimetic activity $(59,60)$, reduction of insulin resistance $(61,62)$, inhibition of pancreatic $\alpha$-amylase and $\alpha$-glucosidase enzymes (63), enhancement of glucose uptake (64), stimulation of glycogen synthesis (65), inhibition of gluconeogenesis (66) and delayed gastric emptying (67).

Addition of cinnamon, improved the glucose control and lipid levels in patients with poorly controlled type 2 diabetes taking sulfonylureas (68). To prevent hypoglycemia, the dose of sulfonylureas may need to be adjusted if the patient is taking cinnamon concurrently.

\section{Gymnema (Gymnema sylvestre)}

Gymnema is a herb found vastly in India and Srilanka. Traditionally, Gymnema is used to treat diabetes, dyspepsia, constipation, jaundice, haemorrhoids, cardiopathy, asthma, bronchitis and leukoderma. In addition, it has been found to contain antidiabetic, antiobesity, hypolipidaemic, antimicrobial, antioxidant, diuretic, antihelmentic and anti-inflammatory properties (69-71). Active phytoconstituents of Gymnema include triterpene saponins (gymnemic acids and gymnemasaponins, gymnemasides), flavones, anthraquinones, resins, alkaloids, etc (72,73). Gymnemic acids of Gymnema is responsible for the antidiabetic activity. Gymnema may reduce the glucose levels by delaying glucose absorption (74), enhancing insulin secretion (75-77), increasing glucose uptake in the liver, kidney and muscle (78) and inducing repair or regeneration of pancreatic beta cells $(79,80)$.

Significant reduction of fasting blood glucose and lipid levels has been noted in patients with type 2 diabetes receiving sulfonylurea treatment along with $400 \mathrm{mg}$ of Gymnema daily for 18 to 20 months $(55,79)$. Concomitant use of sulfonylureas and Gymnema may result in potentiation of hypoglycemic effects $(81,82)$. 


\section{Ginseng}

Ginseng root is a popular herb and there are many varieties of ginseng available including Asian ginseng or Korean ginseng (Panax ginseng) and American ginseng (Panax quinquefolius) (83). Ginseng is used in traditional Chinese medicine (TCM) to treat diabetes, impotence, anorexia, insomnia, palpitation, shortness of breath and hemorrhage (84). The active principles found in ginseng include ginsenosides, polysaccharides, polyynes, flavonoids, peptides, polyacetylenic alcohols and volatile oils (85). The most pharmacologically active constituents of ginseng are ginsenosides and they possess antioxidant, antiinflammatory, anticarcinogenic and immunostimulant properties (86). Ginseng may produce its antihyperglycemic activity by stimulating insulin production and preventing $\beta$ cell loss (87-89), stimulating insulin release (90-93), improving insulin sensitivity (94-96), decreasing insulin resistance $(97,98)$, increasing glucose uptake (99-101), suppressing hepatic glucose production $(102,103)$, improving the regulation of plasma glucose and plasma insulin (104) and improving the expression of peroxisome proliferator-activated receptors $(\operatorname{PPAR} \gamma)(105,106)$. In sum, ginseng may potentiate the hypoglycemic activity of sulfonylureas (107).

\section{Ginger (Zingiber officinale)}

Ginger root is used as a cooking spice in foods. Traditionally ginger is used to treat various conditions including diabetes, asthma, stroke, constipation, rheumatism, nervous diseases, gingivitis, toothache, etc (108). Phytochemical studies of ginger revealed that it contained terpenes (Zingiberene, $\beta$-bisabolene, $\alpha$-farnesene, $\beta$-sesquiphellandrene, and $\alpha$-curcumene), phenolic compounds (Gingerol, paradols, and shogaol), amino acids, raw fiber, ash, protein, phytosterols, vitamins and minerals $(109,110)$. Ginger may exhibit its antihyperglycemic activity through improvement of insulin resistance $(111,112)$, enhancement of glucose uptake $(113,114)$, increased insulin synthesis (115), decreased gluconeogenesis and glycogenolysis and increased glycogenesis (116) and inhibition of a-glucosidase and $\alpha$-amylase enzymes (117).

Concomitant administration of ginger extract ( 25 or 50 $\mathrm{mg} / \mathrm{kg}$ ) and glibenclamide $(5 \mathrm{mg} / \mathrm{kg}$ ) in streptozotocin (STZ)-induced diabetic rats, decreased the non-fasting blood glucose level significantly. The blood glucose levels should be monitored in patients taking sulfonylureas and ginger together, to avoid the occurrence of hypoglycemia (118).

\section{Garlic (Allium sativum)}

Garlic is a natural medicinal plant and is used as a flavoring substance in food preparations. Garlic found helpful to lower blood sugar, reduce cholesterol levels, prevent cardiovascular diseases, enhance the immune system and regulate blood pressure. It is effective against bacterial, viral, fungal and parasitic infections (119). The phytochemicals of garlic include sulfur compounds (allicin, alliin and agoene), volatile oils, enzymes (allinase, peroxidase and miracynase), carbohydrates (sucrose and glucose), minerals (selenium), amino acids (cysteine, glutamine, isoleucine and methionine), bioflavonoids (quercetin and cyanidin, allistatin I and allistatin II) and vitamins ( $\mathrm{C}, \mathrm{E}, \mathrm{A}$, niacin, $\mathrm{B} 1$ and $\mathrm{B} 2$ and betacarotene (120). Sulphur compounds of garlic are linked to the hypoglycemic activity $(121,122)$. Garlic may decrease the blood glucose levels through direct or indirect stimulation of insulin secretion $(123,124)$, enhanced glucose utilization (125) and reduction of glucose absorption (126).

Greater hypoglycemic activity was noted in streptozotocininduced diabetic rats receiving the combination of garlic extract $(500 \mathrm{mg} / \mathrm{kg})$ and glibenclamide $(0.25$ or $0.5 \mathrm{mg} /$ $\mathrm{kg}$ ) than either of the drug given alone (127). Caution should be applied in patients taking sulfonylureas and garlic together $(127,128)$.

\section{Aloe vera (Aloe barbadensis Miller)}

Aloe vera is traditionally used to treat various conditions in many countries. Active components of Aloe vera include anthraquinones (aloin, barbaloin, isobarbaloin, anthranol, etc), hormones (auxins and gibberellins), enzymes (cyclooxygenase, oxidase, amylase, catalase, lipase, alkaline phosphatase, carboxypeptidase), vitamins (B1, B2, B6, choline, folic acid, C, $\alpha$-tocopherol, $\beta$-carotene), minerals (calcium, sodium, chlorine, manganese, zinc, chromium, etc), sugars (cellulose, glucose, mannose, etc), amino acids (lysine, threonine, valine, leucine, isoleucine, phenylalanine, methionine) (129-131). Aloe vera was found to possess therapeutic properties such as antidiabetic, antibacterial, antiviral, antifungal, antiinflammatory, anticancer, antioxidant, wound healing and immunostimulation activities (132-134). Aloe vera may exert its hypoglycemic activity by improving insulin resistance (135-137), stimulating the release of insulin (138), inhibiting pancreatic a-amylase activity (139), increasing glucose utilization and suppressing glucose production (140).

Significant improvement in blood glucose level and lipid levels was seen in diabetic patients taking Aloe vera juice ( $15 \mathrm{~mL}$ two times daily) and glibenclamide (10 mg daily) concurrently (141).

\section{Sesame (Sesamum indicum) oil}

Sesame oil is widely used for cooking in South India and other parts of the world. Sesame oil is composed of lignans (sesamin, sesamolin), minerals, vitamins, phytosterols, unsaturated fatty acids (linoleic acid, oleic acid, etc) and tocopherols (142-144). Many studies have shown that sesame oil has antioxidant, antihypertensive, antihyperlipidemic, antihyperglycemic, anticarcinogenic and immunoregulatory activities (145-148). Diabetes patients may prefer sesame oil as it reduces the detrimental 
effects of diabetes by improving glucose control, blood pressure, lipid levels and cardiac and renal health (149152).

The type 2 diabetes patients taking the combination of sesame oil ( $\sim 35 \mathrm{~g}$ oil/day used in cooking or salad preparation) and glibenclamide (5 $\mathrm{mg}$ daily) showed a greater anti-hyperglycaemic effect (153).

\section{Andrographis paniculata}

Andrographis paniculata is a medicinal plant used traditionally to treat various illnesses like infections, liver problems, diabetes, etc. The principal constituent of $A$. paniculata is androdrographolide, which has been shown to reduce the plasma glucose in streptozotocin-induced diabetic rats by increasing glucose utilization (154).

The hypoglycemic effect of glyburide enhanced considerably by the coadministration with androdrographolide. The herbal preparations containing A. paniculata (androdrographolide) should be used in patients taking sulfonylureas with special attention to avoid the risk of hypoglycemia (155).

\section{Neem (Azadirachta indica)}

Azadirachta indica is a traditionally used medicinal plant, which has anti-inflammatory, immunostimulant and hypoglycemic activities (156). A. indica found to decrease the blood glucose level by improving carbohydrate metabolism through the stimulation of the $\beta$-cells in streptozotocin-induced diabetic mice (157). Concomitant use of aqueous extract of $A$. indica with gliclazide produced good control of blood glucose (158).

\section{Conclusion}

Use of herbal medicines to treat diabetes is getting popular around the world. The herbs like St. John's wort and Gingko biloba induce CYP2C9-mediated metabolism of sulfonylureas while the fruit juices like Pomegranate juice and Pineapple juice inhibit their metabolism. In addition, the antidiabetic herbal supplements such as bitter melon, fenugreek, cinnamon, Gymnema, ginseng, ginger, garlic, Aloe vera, sesame, andrographis paniculata and neem potentiate the hypoglycemic activity of sulfonylureas pharmacodynamically. The prescribers and the pharmacists should be aware of the herbs interacting with sulfonylureas to prevent adverse outcomes.

\section{Authors' contributions}

NMPM and RB conceived the presented idea. NMPM drafted the manuscript. RB reviewed it. All read and confirmed its publication.

\section{Conflict of interests}

None.

\section{Ethical considerations}

Ethical issues including plagiarism, misconduct, data fabrication, falsification, double publication or submission, redundancy, have been carefully observed by authors.

\section{Funding/Support}

None.

\section{References}

1. Rehman SU, Choi MS, Choe K, Yoo HH. Interactions between herbs and antidiabetics: an overview of the mechanisms, evidence, importance, and management. Arch Pharm Res. 2015;38(7):1281-98. doi: 10.1007/s12272014-0517-z.

2. Wild S, Roglic G, Green A, Sicree R, King H. Global prevalence of diabetes: estimates for the year 2000 and projections for 2030. Diabetes Care. 2004;27(5):1047-53.

3. Shaw JE, Sicree RA, Zimmet PZ. Global estimates of the prevalence of diabetes for 2010 and 2030. Diabetes Res Clin Pract. 2010;87(1):4-14. doi: 10.1016/j.diabres.2009.10.007.

4. Whiting DR, Guariguata L, Weil C, Shaw J. IDF diabetes atlas: global estimates of the prevalence of diabetes for 2011 and 2030. Diabetes Res Clin Pract. 2011;94(3):311-21. doi: 10.1016/j.diabres.2011.10.029.

5. Guariguata L, Whiting DR, Hambleton I, Beagley J, Linnenkamp U, Shaw JE. Global estimates of diabetes prevalence for 2013 and projections for 2035. Diabetes Res Clin Pract. 2014;103(2):137-49. doi: 10.1016/j. diabres.2013.11.002.

6. Ogurtsova K, da Rocha Fernandes JD, Huang Y, Linnenkamp U, Guariguata L, Cho NH, et al. IDF Diabetes Atlas: Global estimates for the prevalence of diabetes for 2015 and 2040. Diabetes Res Clin Pract. 2017;128:40-50. doi: $\quad$ 10.1016/j.diabres.2017.03.024.

7. Cho NH, Shaw JE, Karuranga S, Huang Y, da Rocha Fernandes JD, Ohlrogge AW, et al. IDF Diabetes Atlas: Global estimates of diabetes prevalence for 2017 and projections for 2045. Diabetes Res Clin Pract. 2018;138:27181. doi: 10.1016/j.diabres.2018.02.023.

8. Lam DW, LeRoith D. The worldwide diabetes epidemic. Curr Opin Endocrinol Diabetes Obes. 2012;19(2):93-6. doi: 10.1097/MED.0b013e328350583a.

9. Tao Z, Shi A, Zhao J. Epidemiological perspectives of diabetes. Cell Biochem Biophys. 2015;73(1):181-5. doi: 10.1007/s12013-015-0598-4.

10. Reusch JE, Manson JE. Management of type 2 diabetes in 2017: getting to goal. JAMA. 2017;317(10):1015-1016. doi: 10.1001/jama.2017.0241.

11. Majjad A, Errahali Y, Toufik H, H Djossou J, Ghassem MA, Kasouati J, Maghraoui AE. Musculoskeletal disorders in patients with diabetes mellitus: a cross-sectional study. Int J Rheumatol. 2018;2018:3839872.

12. Lifestyle management. Diabetes Care. 2017;40 (Suppl 1):S33-s43. doi: 10.2337/dc17-S007.

13. Pharmacologic Approaches to Glycemic Treatment. Diabetes Care. 2017;40(Suppl 1):S64-s74. doi: 10.2337/ dc17-S011.

14. Henquin JC. Misunderstandings and controversies about the insulin-secreting properties of antidiabetic sulfonylureas. Biochimie. 2017;143:3-9. doi: 10.1016/j. biochi.2017.07.002.

15. Sola D, Rossi L, Schianca GP, Maffioli P, Bigliocca M, Mella $\mathrm{R}$, et al. Sulfonylureas and their use in clinical practice. Arch Med Sci. 2015;11(4):840-8. doi: 10.5114/aoms.2015.53304. 
16. Harris PE, Cooper KL, Relton C, Thomas KJ. Prevalence of complementary and alternative medicine (CAM) use by the general population: a systematic review and update. Int J Clin Pract. 2012;66(10):924-39. doi: 10.1111/j.17421241.2012.02945.x.

17. Egede LE, Ye X, Zheng D, Silverstein MD. The prevalence and pattern of complementary and alternative medicine use in individuals with diabetes. Diabetes Care. 2002;25(2):3249.

18. Garrow D, Egede LE. Association between complementary and alternative medicine use, preventive care practices, and use of conventional medical services among adults with diabetes. Diabetes Care. 2006;29(1):15-9.

19. Chang HY, Wallis M, Tiralongo E. Use of complementary and alternative medicine among people living with diabetes: literature review. J Adv Nurs. 2007;58(4):307-19. doi: $\quad 10.1111 /$ j.1365-2648.2007.04291.x.

20. Rashrash M, Schommer JC, Brown LM. Prevalence and Predictors of Herbal Medicine Use Among Adults in the United States. J Patient Exp. 2017;4(3):108-13. doi: 10.1177/2374373517706612.

21. Qi Z. WHO Traditional Medicine Strategy. 2014-2023. Geneva: World Health Organization; 2013.

22. Algothamy AS, Alruqayb WS, Abdallah MA, Mohamed KM, Albarraq AA, Maghrabi IA. Prevalence of using herbal drugs as anti-diabetic agents in Taif Area, Kingdom of Saudi Arabia. Saudi J Health Sci. 2014;3(3):137-40. doi: 10.4103/2278-0521.142319.

23. Al-Asadi JN, Salih N. Herbal remedies use among diabetic patients in Nassyria, Iraq. Prevalence of childhood obesity among a sample of basic education school children in Erbil City. World Fam Med J. 2012;7(10):1040.

24. Baxter K, Preston CL, eds. Stockley's drug interactions. London: Pharmaceutical Press; 2010.

25. Pakkir Maideen NM, Manavalan G, Balasubramanian K. Drug interactions of meglitinide antidiabetics involving CYP enzymes and OATP1B1 transporter. Therapeutic Advances in Endocrinology and Metabolism. 2018;1-10. doi: $10.1177 / 2042018818767220$.

26. Holstein A, Beil W, Kovacs P. CYP2C metabolism of oral antidiabetic drugs--impact on pharmacokinetics, drug interactions and pharmacogenetic aspects. Expert Opin Drug Metab Toxicol. 2012;8(12):1549-63. doi: $10.1517 / 17425255.2012 .722619$.

27. Holstein A, Beil W. Oral antidiabetic drug metabolism: pharmacogenomics and drug interactions. Expert Opin Drug Metab Toxicol. 2009;5(3):225-41. doi: $10.1517 / 17425250902806424$.

28. Wanwimolruk S, Prachayasittikul V. Cytochrome P450 enzyme mediated herbal drug interactions (Part 1). Excli j. 2014;13:347-91.

29. Xu H, Williams KM, Liauw WS, Murray M, Day RO, McLachlan AJ. Effects of St John's wort and CYP2C9 genotype on the pharmacokinetics and pharmacodynamics of gliclazide. Br J Pharmacol. 2008;153(7):1579-86. doi: 10.1038/sj.bjp.0707685.

30. Sugiyama T, Kubota Y, Shinozuka K, Yamada S, Wu J, Umegaki K. Ginkgo biloba extract modifies hypoglycemic action of tolbutamide via hepatic cytochrome P450 mediated mechanism in aged rats. Life Sci. 2004;75(9):111322. doi: $10.1016 /$ j.lfs.2004.02.020.

31. Uchida S, Yamada H, Li XD, Maruyama S, Ohmori Y, Oki T, et al. Effects of Ginkgo biloba extract on pharmacokinetics and pharmacodynamics of tolbutamide and midazolam in healthy volunteers. J Clin Pharmacol. 2006;46(11):1290-8. doi: $10.1177 / 0091270006292628$.

32. Chakraborty M, Ahmed MG, Bhattacharjee A. The potential for interaction of tolbutamide with pomegranate juice against diabetic induced complications in rats. Integr Med Res. 2017;6(4):354-60. doi: 10.1016/j.imr.2017.07.006.

33. Hidaka M, Nagata M, Kawano Y, Sekiya H, Kai H, Yamasaki $\mathrm{K}$, et al. Inhibitory effects of fruit juices on cytochrome P450 2C9 activity in vitro. Biosci Biotechnol Biochem. 2008;72(2):406-11. doi: 10.1271/bbb.70511.

34. Grover JK, Yadav SP. Pharmacological actions and potential uses of Momordica charantia: a review. J Ethnopharmacol. 2004;93(1):123-32. doi: 10.1016/j.jep.2004.03.035.

35. Rotshteyn Y, Zito SW. Application of modified in vitro screening procedure for identifying herbals possessing sulfonylurea-like activity. J Ethnopharmacol. 2004;93(23):337-44. doi: 10.1016/j.jep.2004.04.007.

36. Leatherdale BA, Panesar RK, Singh G, Atkins TW, Bailey CJ, Bignell AH. Improvement in glucose tolerance due to Momordica charantia (karela). Br Med J (Clin Res Ed). 1981;282(6279):1823-4.

37. Welihinda J, Karunanayake EH, Sheriff MH, Jayasinghe KS. Effect of Momordica charantia on the glucose tolerance in maturity onset diabetes. J Ethnopharmacol. 1986;17(3):27782.

38. Miura T, Itoh C, Iwamoto N, Kato M, Kawai M, Park SR, et al. Hypoglycemic activity of the fruit of the Momordica charantia in type 2 diabetic mice. J Nutr Sci Vitaminol (Tokyo). 2001;47(5):340-4.

39. Cummings E, Hundal HS, Wackerhage H, Hope M, Belle M, Adeghate E, et al. Momordica charantia fruit juice stimulates glucose and amino acid uptakes in L6 myotubes. Mol Cell Biochem. 2004;261(1-2):99-104.

40. Shane-McWhorter L. Biological Complementary Therapies: A Focus on Botanical Products in Diabetes. Diabetes Spectr. 2001;14(4):199-208. doi:10.2337/diaspect.14.4.199.

41. Sridhar MG, Vinayagamoorthi R, Arul Suyambunathan V, Bobby Z, Selvaraj N. Bitter gourd (Momordica charantia) improves insulin sensitivity by increasing skeletal muscle insulin-stimulated IRS-1 tyrosine phosphorylation in highfat-fed rats. Br J Nutr. 2008;99(4):806-12. doi: 10.1017/ s000711450783176x.

42. Basch E, Gabardi S, Ulbricht C. Bitter melon (Momordica charantia): a review of efficacy and safety. Am J Health Syst Pharm. 2003;60(4):356-9.

43. Tongia A, Tongia SK, Dave M. Phytochemical determination and extraction of Momordica charantia fruit and its hypoglycemic potentiation of oral hypoglycemic drugs in diabetes mellitus (NIDDM). Indian J Physiol Pharmacol. 2004;48(2):241-4.

44. Bahmani M, Shirzad H, Mirhosseini M, Mesripour A, Rafieian-Kopaei M. A Review on Ethnobotanical and Therapeutic Uses of Fenugreek (Trigonella foenumgraceum L). J Evid Based Complementary Altern Med. 2016;21(1):53-62. doi: 10.1177/2156587215583405.

45. Wani SA, Kumar P. Fenugreek: A review on its nutraceutical properties and utilization in various food products. J Saudi Soc Agric Sci. 2018;17(2):97-106. doi: 10.1016/j. jssas.2016.01.007.

46. Goyal S, Gupta N, Chatterjee S. Investigating Therapeutic 
Potential of Trigonella foenum-graecum L. as Our Defense Mechanism against Several Human Diseases. J Toxicol. 2016;2016:1250387. doi: 10.1155/2016/1250387.

47. Yu H, Wu M, Lu FR, Xie J, Zheng N, Qin Y, et al. [Effect of Trigonella foenum-graecum 4-hydroxyisoleucine on high-glucose induced insulin resistance in 3T3-L1 adipocytes of mice]. Zhongguo Zhong Xi Yi Jie He Za Zhi. 2013;33(10):1394-9.

48. Lu F, Cai Q, Zafar MI, Cai L, Du W, Jian L, et al. 4-Hydroxyisoleucine improves hepatic insulin resistance by restoring glycogen synthesis in vitro. Int J Clin Exp Med. 2015;8(6):8626-33.

49. Jaiswal N, Maurya CK, Venkateswarlu K, Sukanya P, Srivastava AK, Narender T, et al. 4-Hydroxyisoleucine stimulates glucose uptake by increasing surface GLUT4 level in skeletal muscle cells via phosphatidylinositol-3kinase-dependent pathway. Eur J Nutr. 2012;51(7):893-8. doi: $\quad 10.1007 / \mathrm{s} 00394-012-0374-9$.

50. Vijayakumar MV, Bhat MK. Hypoglycemic effect of a novel dialysed fenugreek seeds extract is sustainable and is mediated, in part, by the activation of hepatic enzymes. Phytother Res. 2008;22(4):500-5. doi: 10.1002/ptr.2351.

51. Puri D, Prabhu KM, Murthy PS. Mechanism of action of a hypoglycemic principle isolated from fenugreek seeds. Indian J Physiol Pharmacol. 2002;46(4):457-62.

52. Singh $A B$, Tamarkar AK, Narender $T$, Srivastava AK. Antihyperglycaemic effect of an unusual amino acid (4-hydroxyisoleucine) in C57BL/KsJ-db/db mice. Nat Prod Res. 2010;24(3):258-65. doi: 10.1080/14786410902836693.

53. Haritha C, Reddy AG, Reddy YR, Anilkumar B. Pharmacodynamic interaction of fenugreek, insulin and glimepiride on sero-biochemical parameters in diabetic Sprague-Dawley rats. Vet World. 2015;8(5):656-63. doi: 10.14202/vetworld.2015.656-663.

54. Satyanarayana S, Kilari EK, Jaladi R, Thomas L, Rajanna S, Rajanna B. Influence of aqueous extract of fenugreek-seed powder on the pharmacodynamics and pharmacokinetics of gliclazide in rats/rabbits. Therapy. 2007;4(4):457-63. doi: 10.2217/14750708.4.4.457.

55. Rai A, Eapen C, Prasanth VG. Interaction of herbs and glibenclamide: a review. ISRN Pharmacol. 2012;2012:659478. doi: 10.5402/2012/659478.

56. Avula B, Smillie TJ, Wang YH, Zweigenbaum J, Khan IA. Authentication of true cinnamon (Cinnamon verum) utilising direct analysis in real time (DART)-QToF-MS. Food Addit Contam Part A Chem Anal Control Expo Risk Assess. 2015;32(1):1-8. doi: 10.1080/19440049.2014.981763.

57. Gruenwald J, Freder J, Armbruester N. Cinnamon and health. Crit Rev Food Sci Nutr. 2010;50(9):822-34. doi: 10.1080/10408390902773052.

58. Al-Dhubiab BE. Pharmaceutical applications and phytochemical profile of Cinnamomum burmannii. Pharmacogn Rev. 2012;6(12):125-31. doi: 10.4103/09737847.99946.

59. Shen Y, Fukushima M, Ito Y, Muraki E, Hosono T, Seki T, et al. Verification of the antidiabetic effects of cinnamon (Cinnamomum zeylanicum) using insulin-uncontrolled type 1 diabetic rats and cultured adipocytes. Biosci Biotechnol Biochem. 2010;74(12):2418-25. doi: 10.1271/ bbb. 100453 .

60. Jarvill-Taylor KJ, Anderson RA, Graves DJ. A hydroxychalcone derived from cinnamon functions as a mimetic for insulin in 3T3-L1 adipocytes. J Am Coll Nutr.
2001;20(4):327-36.

61. Qin B, Nagasaki M, Ren M, Bajotto G, Oshida Y, Sato Y. Cinnamon extract prevents the insulin resistance induced by a high-fructose diet. Horm Metab Res. 2004;36(2):11925. doi: 10.1055/s-2004-814223.

62. Sheng X, Zhang Y, Gong Z, Huang C, Zang YQ. Improved Insulin Resistance and Lipid Metabolism by Cinnamon Extract through Activation of Peroxisome ProliferatorActivated Receptors. PPAR Res. 2008;2008:581348. doi: $10.1155 / 2008 / 581348$

63. Adisakwattana S, Lerdsuwankij O, Poputtachai U, Minipun A, Suparpprom C. Inhibitory activity of cinnamon bark species and their combination effect with acarbose against intestinal alpha-glucosidase and pancreatic alpha-amylase. Plant Foods Hum Nutr. 2011;66(2):143-8. doi: 10.1007/ s11130-011-0226-4.

64. Kim W, Khil LY, Clark R, Bok SH, Kim EE, Lee $S$, et al. Naphthalenemethyl ester derivative of dihydroxyhydrocinnamic acid, a component of cinnamon, increases glucose disposal by enhancing translocation of glucose transporter 4. Diabetologia. 2006;49(10):2437-48. doi: 10.1007/s00125-006-0373-6.

65. Khan A, Safdar M, Ali Khan MM, Khattak KN, Anderson RA. Cinnamon improves glucose and lipids of people with type 2 diabetes. Diabetes Care. 2003;26(12):3215-8.

66. Anand P, Murali KY, Tandon V, Murthy PS, Chandra R. Insulinotropic effect of cinnamaldehyde on transcriptional regulation of pyruvate kinase, phosphoenolpyruvate carboxykinase, and GLUT4 translocation in experimental diabetic rats. Chem Biol Interact. 2010;186(1):72-81. doi: 10.1016/j.cbi.2010.03.044.

67. Hlebowicz J, Darwiche G, Bjorgell O, Almer LO. Effect of cinnamon on postprandial blood glucose, gastric emptying, and satiety in healthy subjects. Am J Clin Nutr. 2007;85(6):1552-6. doi: 10.1093/ajcn/85.6.1552.

68. Geil P, Shane-McWhorter L. Dietary supplements in the management of diabetes: potential risks and benefits. J Am Diet Assoc. 2008;108(4 Suppl 1):S59-65. doi: 10.1016/j. jada.2008.01.020.

69. Di Fabio G, Romanucci V, Di Marino C, Pisanti A, Zarrelli A. Gymnema sylvestre R. Br., an Indian medicinal herb: traditional uses, chemical composition, and biological activity. Curr Pharm Biotechnol. 2015;16(6):506-16.

70. Saneja A, Sharma C, Aneja KR, Pahwa R. Gymnema sylvestre (Gurmar): A review. Pharm Lett. 2010;2(1):275-84.

71. Singh VK, Umar S, Ansari SA, Iqbal M. Gymnema sylvestre for Diabetics. J Herbs Spices Med Plants. 2008;14(1-2):88106. doi: 10.1080/10496470802341508.

72. Tiwari P, Mishra BN, Sangwan NS. Phytochemical and pharmacological properties of Gymnema sylvestre: an important medicinal plant. Biomed Res Int. 2014;2014:830285. doi: 10.1155/2014/830285.

73. Vaidya S. Review on gymnema: an herbal medicine for diabetes management. Pharmacia. 2011;1(2):37-42.

74. Pothuraju R, Sharma RK, Chagalamarri J, Jangra S, Kumar Kavadi P. A systematic review of Gymnema sylvestre in obesity and diabetes management. J Sci Food Agric. 2014;94(5):834-40. doi: 10.1002/jsfa.6458.

75. Al-Romaiyan A, King AJ, Persaud SJ, Jones PM. A novel extract of Gymnema sylvestre improves glucose tolerance in vivo and stimulates insulin secretion and synthesis in vitro. Phytother Res. 2013;27(7):1006-11. doi: 10.1002/ptr.4815.

76. Al-Romaiyan A, Liu B, Asare-Anane H, Maity CR, 
Chatterjee SK, Koley N, et al. A novel Gymnema sylvestre extract stimulates insulin secretion from human islets in vivo and in vitro. Phytother Res. 2010;24(9):1370-6. doi: 10.1002/ptr.3125.

77. Persaud SJ, Al-Majed H, Raman A, Jones PM. Gymnema sylvestre stimulates insulin release in vitro by increased membrane permeability. J Endocrinol. 1999;163(2):207-12.

78. Shanmugasundaram KR, Panneerselvam C, Samudram P, Shanmugasundaram ER. Enzyme changes and glucose utilisation in diabetic rabbits: the effect of Gymnema sylvestre, R.Br. J Ethnopharmacol. 1983;7(2):205-34.

79. Baskaran K, Kizar Ahamath B, Radha Shanmugasundaram $\mathrm{K}$, Shanmugasundaram ER. Antidiabetic effect of a leaf extract from Gymnema sylvestre in non-insulindependent diabetes mellitus patients. J Ethnopharmacol. 1990;30(3):295-300.

80. Shanmugasundaram ER, Gopinath KL, Radha Shanmugasundaram K, Rajendran VM. Possible regeneration of the islets of Langerhans in streptozotocindiabetic rats given Gymnema sylvestre leaf extracts. J Ethnopharmacol. 1990;30(3):265-79.

81. Kamble B, Gupta A, Moothedath I, Khatal L, Janrao S, Jadhav A, et al. Effects of Gymnema sylvestre extract on the pharmacokinetics and pharmacodynamics of glimepiride in streptozotocin induced diabetic rats. Chem Biol Interact. 2016;245:30-8. doi: 10.1016/j.cbi.2015.12.008.

82. Raju MG, Satyanarayana S, Kumar E. Safety of gliclazide with the aqueous extract of Gymnema sylvestre on pharmacodynamic activity in normal and alloxan induced diabetic rats. Am J Phytomed Clin Ther. 2014;2(7):901-9.

83. Sievenpiper JL, Arnason JT, Leiter LA, Vuksan V. Decreasing, null and increasing effects of eight popular types of ginseng on acute postprandial glycemic indices in healthy humans: the role of ginsenosides. J Am Coll Nutr. 2004;23(3):248-58.

84. Xiang YZ, Shang HC, Gao XM, Zhang BL. A comparison of the ancient use of ginseng in traditional Chinese medicine with modern pharmacological experiments and clinical trials. Phytother Res. 2008;22(7):851-8. doi: 10.1002/ ptr.2384.

85. Jia L, Zhao Y. Current evaluation of the millennium phytomedicine--ginseng (I): etymology, pharmacognosy, phytochemistry, market and regulations. Curr Med Chem. 2009;16(19):2475-84.

86. Attele AS, Wu JA, Yuan CS. Ginseng pharmacology: multiple constituents and multiple actions. Biochem Pharmacol. 1999;58(11):1685-93.

87. Kim HY, Kim K. Protective effect of ginseng on cytokineinduced apoptosis in pancreatic beta-cells. J Agric Food Chem. 2007;55(8):2816-23. doi: 10.1021/jf062577r.

88. Wu Z, Luo JZ, Luo L. American ginseng modulates pancreatic beta cell activities. Chin Med. 2007;2:11. doi: 10.1186/1749-8546-2-11.

89. Luo JZ, Luo L. American ginseng stimulates insulin production and prevents apoptosis through regulation of uncoupling protein-2 in cultured beta cells. Evid Based Complement Alternat Med. 2006;3(3):365-72. doi: 10.1093/ ecam/nel026.

90. Park S, Ahn IS, Kwon DY, Ko BS, Jun WK. Ginsenosides $\mathrm{Rb} 1$ and Rg1 suppress triglyceride accumulation in 3T3L1 adipocytes and enhance beta-cell insulin secretion and viability in Min6 cells via PKA-dependent pathways. Biosci Biotechnol Biochem. 2008;72(11):2815-23. doi: 10.1271/ bbb. 80205 .

91. Kim K, Kim HY. Korean red ginseng stimulates insulin release from isolated rat pancreatic islets. J Ethnopharmacol. 2008;120(2):190-5. doi: 10.1016/j.jep.2008.08.006.

92. Lee WK, Kao ST, Liu IM, Cheng JT. Increase of insulin secretion by ginsenoside $\mathrm{Rh} 2$ to lower plasma glucose in Wistar rats. Clin Exp Pharmacol Physiol. 2006;33(1-2):2732. doi: 10.1111/j.1440-1681.2006.04319.x.

93. Park MW, Ha J, Chung SH. 20(S)-ginsenoside Rg3 enhances glucose-stimulated insulin secretion and activates AMPK. Biol Pharm Bull. 2008;31(4):748-51.

94. Lee SH, Lee HJ, Lee YH, Lee BW, Cha BS, Kang ES, et al. Korean red ginseng (Panax ginseng) improves insulin sensitivity in high fat fed Sprague-Dawley rats. Phytother Res. 2012;26(1):142-7. doi: 10.1002/ptr.3610.

95. Lee HJ, Lee YH, Park SK, Kang ES, Kim HJ, Lee YC, et al. Korean red ginseng (Panax ginseng) improves insulin sensitivity and attenuates the development of diabetes in Otsuka Long-Evans Tokushima fatty rats. Metabolism. 2009;58(8):1170-7. doi: 10.1016/j.metabol.2009.03.015.

96. Lee WK, Kao ST, Liu IM, Cheng JT. Ginsenoside Rh2 is one of the active principles of Panax ginseng root to improve insulin sensitivity in fructose-rich chow-fed rats. Horm Metab Res. 2007;39(5):347-54. doi: 10.1055/s-2007-976537.

97. Zhang Z, Li X, Lv W, Yang Y, Gao H, Yang J, et al. Ginsenoside Re reduces insulin resistance through inhibition of c-Jun NH2-terminal kinase and nuclear factor-kappaB. Mol Endocrinol. 2008;22(1):186-95. doi: 10.1210/me.20070119.

98. Liu TP, Liu IM, Cheng JT. Improvement of insulin resistance by panax ginseng in fructose-rich chow-fed rats. Horm Metab Res. 2005;37(3):146-51. doi: 10.1055/s-2005-861299.

99. Lee HM, Lee OH, Kim KJ, Lee BY. Ginsenoside Rg1 promotes glucose uptake through activated AMPK pathway in insulin-resistant muscle cells. Phytother Res. 2012;26(7):1017-22. doi: 10.1002/ptr.3686.

100. Lee OH, Lee HH, Kim JH, Lee BY. Effect of ginsenosides Rg3 and Re on glucose transport in mature 3T3-L1 adipocytes. Phytother Res. 2011;25(5):768-73. doi: 10.1002/ptr.3322.

101. Huang YC, Lin CY, Huang SF, Lin HC, Chang WL, Chang TC. Effect and mechanism of ginsenosides CK and Rg1 on stimulation of glucose uptake in 3T3-L1 adipocytes. J Agric Food Chem. 2010;58(10):6039-47. doi: 10.1021/jf9034755.

102. Kim DY, Yuan HD, Huang B, Quan HY, Chung SH. Ginsenoside 20(R)-Rg3 stimulates glucose uptake in C2C12 myotubes via CaMKK-AMPK pathways. Food Sci Biotechnol. 2010;19(5):1277-82. doi: 10.1007/s10068-0100182-z.

103. Kim SJ, Yuan HD, Chung SH. Ginsenoside Rg1 suppresses hepatic glucose production via AMP-activated protein kinase in HepG2 cells. Biol Pharm Bull. 2010;33(2):325-8.

104. Vuksan V, Sung MK, Sievenpiper JL, Stavro PM, Jenkins AL, Di Buono M, et al. Korean red ginseng (Panax ginseng) improves glucose and insulin regulation in well-controlled, type 2 diabetes: results of a randomized, double-blind, placebo-controlled study of efficacy and safety. Nutr Metab Cardiovasc Dis. 2008;18(1):46-56. doi: 10.1016/j. numecd.2006.04.003.

105. Shang W, Yang Y, Jiang B, Jin H, Zhou L, Liu S, et al. Ginsenoside Rb1 promotes adipogenesis in 3T3-L1 cells by enhancing PPARgamma2 and C/EBPalpha gene expression. Life Sci. 2007;80(7):618-25. doi: 10.1016/j.lfs.2006.10.021. 106. Ni HX, Yu NJ, Yang XH. The study of ginsenoside on 
PPARgamma expression of mononuclear macrophage in type 2 diabetes. Mol Biol Rep. 2010;37(6):2975-9. doi: 10.1007/s11033-009-9864-0.

107. Anastasi JK, Chang M, Capili B. Herbal supplements: talking with your patients. J Nurse Pract. 2011;7(1):29-35. doi: $10.1016 /$ j.nurpra.2010.06.004.

108. Ali BH, Blunden G, Tanira MO, Nemmar A. Some phytochemical, pharmacological and toxicological properties of ginger (Zingiber officinale Roscoe): a review of recent research. Food Chem Toxicol. 2008;46(2):409-20. doi: $\quad$ 10.1016/j.fct.2007.09.085.

109. Prasad S, Tyagi AK. Ginger and its constituents: role in prevention and treatment of gastrointestinal cancer. Gastroenterol Res Pract. 2015;2015:142979. doi: $10.1155 / 2015 / 142979$.

110. Wang CZ, Qi LW, Yuan CS. Cancer Chemoprevention Effects of Ginger and its Active Constituents: Potential for New Drug Discovery. Am J Chin Med. 2015;43(7):1351-63. doi: $10.1142 / \mathrm{s} 0192415 \times 15500767$.

111. Akash MS, Rehman K, Tariq M, Chen S. Zingiber officinale and Type 2 Diabetes Mellitus: Evidence from Experimental Studies. Crit Rev Eukaryot Gene Expr. 2015;25(2):91-112.

112. Mozaffari-Khosravi H, Talaei B, Jalali BA, Najarzadeh A, Mozayan MR. The effect of ginger powder supplementation on insulin resistance and glycemic indices in patients with type 2 diabetes: a randomized, double-blind, placebocontrolled trial. Complement Ther Med. 2014;22(1):9-16. doi: 10.1016/j.ctim.2013.12.017

113. Li Y, Tran VH, Duke CC, Roufogalis BD. Gingerols of Zingiber officinale enhance glucose uptake by increasing cell surface GLUT4 in cultured L6 myotubes. Planta Med. 2012;78(14):1549-55. doi: 10.1055/s-0032-1315041.

114. Rani MP, Krishna MS, Padmakumari KP, Raghu KG, Sundaresan A. Zingiber officinale extract exhibits antidiabetic potential via modulating glucose uptake, protein glycation and inhibiting adipocyte differentiation: an in vitro study. J Sci Food Agric. 2012;92(9):1948-55. doi: $10.1002 /$ jsfa. 5567.

115. Islam MS, Choi H. Comparative effects of dietary ginger (Zingiber officinale) and garlic (Allium sativum) investigated in a type 2 diabetes model of rats. J Med Food. 2008;11(1):152-9. doi: 10.1089/jmf.2007.634.

116. Son MJ, Miura Y, Yagasaki K. Mechanisms for antidiabetic effect of gingerol in cultured cells and obese diabetic model mice. Cytotechnology. 2015;67(4):641-52. doi: 10.1007/ s10616-014-9730-3.

117. Rani MP, Padmakumari KP, Sankarikutty B, Cherian OL, Nisha VM, Raghu KG. Inhibitory potential of ginger extracts against enzymes linked to type 2 diabetes, inflammation and induced oxidative stress. Int $\mathrm{J}$ Food Sci Nutr. 2011;62(2):106-10. doi: 10.3109/09637486.2010.515565.

118. Al-Omari IL, Afifi FU, Salhab AS. Therapeutic effect and possible herb drug interactions of ginger (Zingiber officinale Roscoe, Zingiberaceae) crude extract with glibenclamide and insulin. Phcog Commn. 2012;2(1):12-20. doi: 10.5530/ pc.2012.1.4.

119. Augusti KT. Therapeutic values of onion (Allium cepa L.) and garlic (Allium sativum L.). Indian J Exp Biol. 1996;34(7):634-40.

120. Ayaz E, Alpsoy HC. [Garlic (Allium sativum) and traditional medicine]. Turkiye Parazitol Derg. 2007;31(2):145-9.

121. Sheela CG, Kumud K, Augusti KT. Anti-diabetic effects of onion and garlic sulfoxide amino acids in rats. Planta Med. 1995;61(4):356-7. doi: 10.1055/s-2006-958099.

122. Sheela CG, Augusti KT. Antidiabetic effects of S-allyl cysteine sulphoxide isolated from garlic Allium sativum Linn. Indian J Exp Biol. 1992;30(6):523-6.

123. El-Demerdash FM, Yousef MI, El-Naga NI. Biochemical study on the hypoglycemic effects of onion and garlic in alloxan-induced diabetic rats. Food Chem Toxicol. 2005;43(1):57-63. doi: 10.1016/j.fct.2004.08.012.

124. Thomson M, Al-Amin ZM, Al-Qattan KK, Shaban LH, Ali M. Anti-diabetic and hypolipidaemic properties of garlic (Allium sativum) in streptozotocin-induced diabetic rats. Int J Diabetes Metab. 2007;15:108-5.

125. Eidi A, Eidi M, Esmaeili E. Antidiabetic effect of garlic (Allium sativum L.) in normal and streptozotocin-induced diabetic rats. Phytomedicine. 2006;13(9-10):624-9. doi: 10.1016/j.phymed.2005.09.010.

126. Mostofa M, Choudhury ME, Hossain MA, Islam MZ, Islam MS, Sumon MH. Antidiabetic effects of Catharanthus roseus, Azadirachta indica, Allium sativum and glimepride in experimentally diabetic induced rat. Bangladesh J Vet Med. 2007:2(1-2):99-102. doi: 10.3329/bjvm.v5il.1324.

127. Poonam T, Prakash GP, Kumar LV. Influence of Allium sativum extract on the hypoglycemic activity of glibenclamide: an approach to possible herb-drug interaction. Drug Metabol Drug Interact. 2013;28(4):22530. doi: 10.1515/dmdi-2013-0031.

128. Khayatnouri M, Bahari K, Safarmashaei S. Study of the effect of gliclazide and garlic extract on blood sugar level in STZinduced diabetic male mice. Advances in Environmental Biology. 2011;5(7):1751-6.

129. Joseph B, Raj SJ. Pharmacognostic and Phytochemical Properties of Aloe vera Linn-An Overview. Int J Pharm Sci Rev Res. 2010;4(2):106-10.

130. Surjushe A, Vasani R, Saple DG. Aloe vera: a short review. Indian J Dermatol. 2008;53(4):163-6. doi: 10.4103/00195154.44785.

131. Shelton RM. Aloe Vera. Int J Dermatol. 1991;30(10):679-83. doi:10.1111/j.1365-4362.1991.tb02607.x.

132. Hamman JH. Composition and applications of Aloe vera leaf gel. Molecules. 2008;13(8):1599-616.

133. Vogler BK, Ernst E. Aloe vera: a systematic review of its clinical effectiveness. Br J Gen Pract. 1999;49(447):823-8.

134. Sahu PK, Giri DD, Singh R, Pandey P, Gupta S, Kumar Shrivastava A, et al. Therapeutic and medicinal uses of Aloe vera: a review. Pharmacol Pharm. 2013;4(8):599-610. doi: 10.4236/pp.2013.48086.

135. Shin E, Shim KS, Kong H, Lee S, Shin S, Kwon J, et al. Dietary Aloe Improves Insulin Sensitivity via the Suppression of Obesity-induced Inflammation in Obese Mice. Immune Netw. 2011;11(1):59-67. doi: 10.4110/in.2011.11.1.59.

136. Perez YY, Jimenez-Ferrer E, Zamilpa A, HernandezValencia M, Alarcon-Aguilar FJ, Tortoriello J, et al. Effect of a polyphenol-rich extract from Aloe vera gel on experimentally induced insulin resistance in mice. Am J Chin Med. 2007;35(6):1037-46. doi: 10.1142/ s0192415x07005491.

137. Kim K, Kim H, Kwon J, Lee S, Kong H, Im SA, et al. Hypoglycemic and hypolipidemic effects of processed Aloe vera gel in a mouse model of non-insulin-dependent diabetes mellitus. Phytomedicine. 2009;16(9):856-63. doi: 10.1016/j.phymed.2009.02.014. 
138. Ajabnoor MA. Effect of aloes on blood glucose levels in normal and alloxan diabetic mice. J Ethnopharmacol. 1990;28(2):215-20.

139. Sudha P, Zinjarde SS, Bhargava SY, Kumar AR. Potent alphaamylase inhibitory activity of Indian Ayurvedic medicinal plants. BMC Complement Altern Med. 2011;11:5. doi: 10.1186/1472-6882-11-5.

140. Suksomboon N, Poolsup N, Punthanitisarn S. Effect of Aloe vera on glycaemic control in prediabetes and type 2 diabetes: a systematic review and meta-analysis. J Clin Pharm Ther. 2016;41(2):180-8. doi: 10.1111/jcpt.12382.

141. Bunyapraphatsara N, Yongchaiyudha S, Rungpitarangsi V, Chokechaijaroenporn O. Antidiabetic activity of Aloe vera L. juice II. Clinical trial in diabetes mellitus patients in combination with glibenclamide. Phytomedicine. 1996;3(3):245-8. doi: 10.1016/s0944-7113(96)80061-4.

142. Pathak N, Rai AK, Kumari R, Bhat KV. Value addition in sesame: A perspective on bioactive components for enhancing utility and profitability. Pharmacogn Rev. 2014;8(16):147-55. doi: 10.4103/0973-7847.134249.

143. Osawa T, Nagata M, Namiki M, Fukuda Y. Sesamolinol, a Novel Antioxidant Isolated from Sesame Seeds. Agric Biol Chem. 1985;49(11):3351-2. doi: 10.1271/bbb1961.49.3351.

144. Lyon CK. Sesame: Current knowledge of composition and use. J Am Oil Chem Soc. 1972;49(4):245-9. doi: 10.1007/ BF02582586.

145. Gouveia Lde A, Cardoso CA, de Oliveira GM, Rosa G, Moreira AS. Effects of the Intake of Sesame Seeds (Sesamum indicum L.) and Derivatives on Oxidative Stress: A Systematic Review. J Med Food. 2016;19(4):337-45. doi: 10.1089/jmf.2015.0075.

146. Haidari F, Mohammadshahi M, Zarei M, Gorji Z. Effects of Sesame Butter (Ardeh) versus Sesame Oil on Metabolic and Oxidative Stress Markers in Streptozotocin-Induced Diabetic Rats. Iran J Med Sci. 2016;41(2):102-9.

147. Wan Y, Li H, Fu G, Chen X, Chen F, Xie M. The relationship of antioxidant components and antioxidant activity of sesame seed oil. J Sci Food Agric. 2015;95(13):2571-8. doi: 10.1002/jsfa.7035.

148. Namiki M. Nutraceutical functions of sesame: a review. Crit Rev Food Sci Nutr. 2007;47(7):651-73. doi: $10.1080 / 10408390600919114$.

149. Aslam F, Iqbal S, Nasir M, Anjum AA, Swan P, Sweazea K.
Evaluation of White Sesame Seed Oil on Glucose Control and Biomarkers of Hepatic, Cardiac, and Renal Functions in Male Sprague-Dawley Rats with Chemically Induced Diabetes. J Med Food. 2017;20(5):448-57. doi: 10.1089/ jmf.2016.0065.

150. Abbasi Z, Tabatabaei SR, Mazaheri Y, Barati F, Morovvati $\mathrm{H}$. Effects of sesame oil on the reproductive parameters of diabetes mellitus-induced male rats. World J Mens Health. 2013;31(2):141-9. doi: 10.5534/wjmh.2013.31.2.141.

151. Khaneshi F, Nasrolahi O, Azizi S, Nejati V. Sesame effects on testicular damage in streptozotocin-induced diabetes rats. Avicenna J Phytomed. 2013;3(4):347-55.

152. Sankar D, Rao MR, Sambandam G, Pugalendi KV. A pilot study of open label sesame oil in hypertensive diabetics. J Med Food. 2006;9(3):408-12. doi: 10.1089/jmf.2006.9.408.

153. Sankar D, Ali A, Sambandam G, Rao R. Sesame oil exhibits synergistic effect with anti-diabetic medication in patients with type 2 diabetes mellitus. Clin Nutr. 2011;30(3):351-8. doi: 10.1016/j.clnu.2010.11.005.

154. Yu BC, Hung CR, Chen WC, Cheng JT. Antihyperglycemic effect of andrographolide in streptozotocin-induced diabetic rats. Planta Med. 2003;69(12):1075-9. doi: 10.1055/ s-2003-45185.

155. Samala S, Veeresham C. Pharmacokinetic and Pharmacodynamic Interaction of Boswellic Acids and Andrographolide with Glyburide in Diabetic Rats: Including Its PK/PD Modeling. Phytother Res. 2016;30(3):496-502. doi: $10.1002 /$ ptr.5556.

156. Khosla P, Bhanwra S, Singh J, Seth S, Srivastava RK. A study of hypoglycaemic effects of Azadirachta indica (Neem) in normaland alloxan diabetic rabbits. Indian J Physiol Pharmacol. 2000;44(1):69-74.

157. Bhat M, Kothiwale SK, Tirmale AR, Bhargava SY, Joshi BN. Antidiabetic Properties of Azardiracta indica and Bougainvillea spectabilis: In Vivo Studies in Murine Diabetes Model. Evid Based Complement Alternat Med. 2011;2011:561625. doi: 10.1093/ecam/nep033.

158. Satyanarayana S, Eswar Kumar K, Cooty T, Rajanna S, Rajanna B. Influence of an aqueous extract of Azadirachta indica leaf on the pharmacodynamics and pharmacokinetics of gliclazide in rats and rabbits. J Herbs Spices Med Plants. 2009;15(1):16-23. doi: 10.1080/10496470902787451. 